Article

\title{
Facile Synthesis of a Polycatenane Compound Based on Ag-triazole Complexes and Phosphomolybdic Acid for the Catalytic Epoxidation of Olefins with Molecular Oxygen
}

\author{
Juan Du ${ }^{1,2}$, Xinyu Liu ${ }^{1,2}$, Jiaxin Zhang ${ }^{1,2}$, Yucun Liu ${ }^{1,2}$, Enwei Zhu ${ }^{1,2}$, Guangbo Che ${ }^{1,2, *}$ and \\ Mingjun Jia ${ }^{3, *(D)}$ \\ 1 Key Laboratory of Preparation and Application of Environmental Friendly Materials \\ (Jilin Normal University), Ministry of Education, Changchun 130103, China \\ 2 Key Laboratory of Functional Materials Physics and Chemistry of the Ministry of Education, \\ Jilin Normal University, Changchun 130103, China \\ 3 College of Chemistry, Jilin University, Changchun 130021, China \\ * Correspondence: guangbc2000@yahoo.com.cn (G.C.); jiamj@jlu.edu.cn (M.J.); \\ Tel.: +86-434-3295100 (G.C.); +86-431-85155390 (M.J.)
}

Received: 30 May 2019; Accepted: 24 June 2019; Published: 26 June 2019

\begin{abstract}
A simple and efficient approach was developed for synthesizing a metal-organic polycatenated compound composed of Ag-triazole complexes and phosphomolybdic acid (PMA) clusters. The hybrid compound, namely $\left\{\left[\mathrm{Ag}_{2}(\operatorname{trz})_{2}\right]\left[\mathrm{Ag}_{24}(\operatorname{trz})_{18}\right]\right\}\left[\mathrm{PMo}_{12} \mathrm{O}_{40}\right]_{2}$ (1) (trz = 1,2,4-triazole), showed high catalytic activity, selectivity and recyclability for the epoxidation of olefins with molecular oxygen as the oxidant and isobutyraldehyde as the co-reagent, and could even work well under ambient conditions. The special polycatenane framework, formed by interlocking $\left[\mathrm{Ag}_{24}(\operatorname{trz})_{18}\right]^{6+}$ nanocages, provides suitable space for filling the PMA clusters. The existence of multi-interactions, including $\pi-\pi$ stacking, Ag-Ag interactions, and electrostatic interactions, should play a determinative role in fabricating the catalytically active and stable PMA-based polycatenane catalyst for aerobic epoxidation of olefins.
\end{abstract}

Keywords: metal-organic polycatenane; heterogeneous catalysis; aerobic epoxidation; olefin

\section{Introduction}

Recently, a new family of supramolecular assemblies based on metal-organic compounds and polyoxometalates (POMs) has attracted great interest due to their potential applications in material science, magnetism, electrochemistry, nanomaterials, and catalysis [1-6]. As commonly used ligands, $\mathrm{N}$-donor bridging bis(triazole) compounds have shown great advantages in constructing the POM-based metal-organic compounds with special structure and physicochemical properties [7-12]. Compared with conventional bipyridine ligands, bis(triazole) ligands are more flexible and have more coordination sites, which allow them to better conform to the coordination environments of POMs and metal cations.

By utilizing triazole and its derivatives as bridging ligands, some novel POM-based metal-organic compounds have been obtained [13-17]. Among them, a very interesting example reported by $\mathrm{Lu}^{\prime}$ s group showed that an infinite three-dimensional polycatenated framework of $\left\{\left[\mathrm{Ag}_{2}(\operatorname{trz})_{2}\right]\left[\mathrm{Ag}_{24}(\operatorname{trz})_{18}\right]\right\}\left[\mathrm{PW}_{12} \mathrm{O}_{40}\right]_{2}$ (trz=1,2,4-triazole) could be synthesized by a hydrothermal reaction of trilacunary Keggin $\mathrm{Na} 9\left[A-\mathrm{PW}_{9} \mathrm{O}_{34}\right] \cdot 7 \mathrm{H}_{2} \mathrm{O}, \mathrm{Ag}\left(\mathrm{O}_{2} \mathrm{CCH}_{3}\right)$ and 1,2,4-trialzole [17]. The framework of the compound is composed of catenated polyhedral cages, which are constructed by mechanical interlocking of all of the vertices of the cages. The penetration of polycatenanes creates 
nanosized voids for accommodating the POM anions, thus resulting in the formation of interpenetrated supramolecular architectures. Notably, the examples of the POMs-based polycatenated framework are rather rare, and it would be highly desirable to study its physicochemical properties, including its catalytic properties. However, the relatively complicated synthesis procedure, the usage of the scarcely used reagent of $\mathrm{Na}_{9}\left[A-\mathrm{PW}_{9} \mathrm{O}_{34}\right] \cdot 7 \mathrm{H}_{2} \mathrm{O}$ ), as well as the low synthesis yield (below $50 \%$ based on $\mathrm{W}$ ) are a serious limitation towards further exploring the structure and function of this hybrid material.

Recently, Sha and coworkers reported a new route to synthesize three new POM-based Ag-trz compounds with polycatenane structure, which contain different Keggin ions $\left(\left[\mathrm{SiW}_{12} \mathrm{O}_{40}\right]^{4-}\right.$, $\left[\mathrm{AsW}_{12} \mathrm{O}_{40}\right]^{3-},\left[\mathrm{PMo}_{12} \mathrm{O}_{40}\right]^{3-}$ ) [18]. In their work, corresponded polyoxometalic acid could be directly used for the synthesis of the hybrid compounds in case of a certain amount of $\mathrm{NH}_{4} \mathrm{VO}_{3}$ was added into the synthesis system. These POM-based polycatenanes exhibited promising discharge capacity and stable electrochemical performance as an anode material in Li-ion batteries.

In this work, we reported a very simple and efficient method for the synthesis of PMA-based Ag-trz polycatenane compound. The resulting compound was characterized by a variety of characterization means, and its catalytic performance was investigated for the so-called "Mukaiyama" epoxidation of olefins, in which molecular oxygen was used as the oxidant and isobutyraldehyde was used as the co-reagent. Previous literature studies suggested that a few Ag-complexes are moderately active homogeneous catalysts for these attractive $\mathrm{O}_{2}$-mediated hydrocarbon/olefin oxidation processes [19-24]. Our present work shows that the hybrid polycatenane compound shows much higher catalytic activity than the corresponded POM or Ag-trz complexes. More interesting, the hybrid compound is quite stable and easily recycled under the tested conditions, which could act as truly heterogeneous catalyst for achieving the molecular oxygen activation at quite a mild reaction condition.

\section{Results and Discussions}

\subsection{Synthesis and Structure of the Catalysts}

The one-pot reaction for the synthesis of catalyst 1 was used, which similar to the literature [17]. Some modifications were made in order to improve the successful rates and the product yield. For instance, the unsaturated phosphotungstic acid $\mathrm{Na}_{9}\left[A-\mathrm{PW}_{9} \mathrm{O}_{34}\right] \cdot 7 \mathrm{H}_{2} \mathrm{O}$ was used for the synthesis of catalyst 1 in the literature [17], which needs to be synthesized aforehand. Our present work confirmed that the usage of $\mathrm{Na}_{9}\left[A-\mathrm{PW}_{9} \mathrm{O}_{34}\right] \cdot 7 \mathrm{H}_{2} \mathrm{O}$ was not the best option due to the cumbersome synthesis strategy and the very low yield. A simpler synthesis strategy and relatively high yield of catalyst 1 can be achieved by optimizing synthesis conditions as described in the experimental section.

X-ray single crystal diffraction analysis revealed that catalyst $\mathbf{1}$ has a metal-organic polycatenation structure consisted of a three-dimensional infinite metal-organic polycatenatied framework and $\left[\mathrm{PMo}_{12} \mathrm{O}_{40}\right]^{3-}$ polyanions (Figure 1). This structure is consistent with the previous reported structure in literature [17]. As shown in Figure $2 \mathrm{a}, \mathrm{Ag}^{+}$cations and triazole ligands generated the $\left\{\mathrm{Ag}_{24}(\operatorname{trz})_{18}\right\}^{6+}$ nanocage through Ag-N bonds. One nanocage, which has six-connected vertex angles, interlocked with other six ones through its vertices to form a 3D polycatenated framework (Figure 2b). The twofold $3 \mathrm{D}$ polycatenated frameworks interpenetrate one another to form the final structure (Figure 2c). PMA anions and Ag-trz framework combined through charge interactions between terminal oxygen atoms in polyanions and $\mathrm{Ag}^{+}$atoms in the 3-D framework. The Keggin $\left[\mathrm{PW}_{12} \mathrm{O}_{40}\right]^{3-}$ polyanions function not only as counteranions but also as templates to direct the formation of the polycatenated framework. 


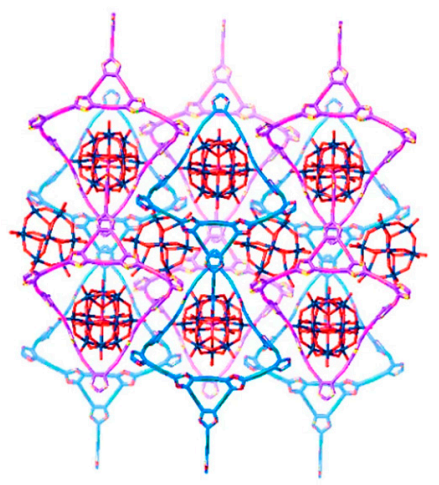

Figure 1. The metal-organic polycatenation structure of catalyst 1.

(a)

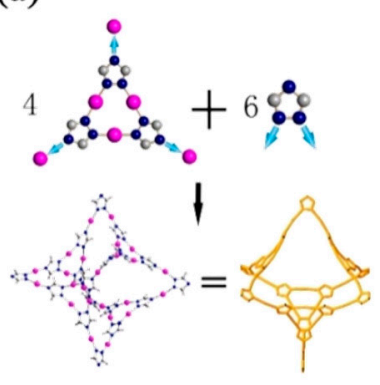

(b)

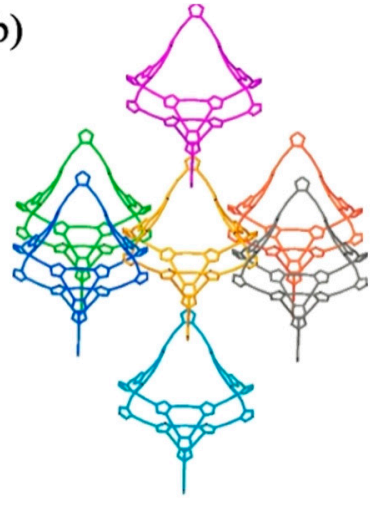

(c)

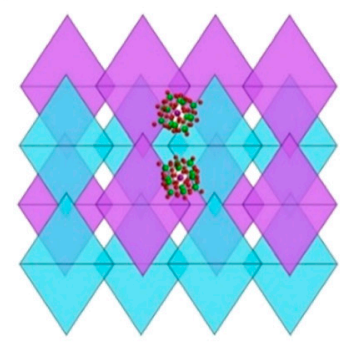

Figure 2. (a) The structure of one $\left\{\mathrm{Ag}_{24}(\operatorname{trz})_{18}\right\}^{6+}$ nanocage. (b) View of a $\left\{\mathrm{Ag}_{24}(\operatorname{trz})_{18}\right\}^{6+}$ nanocage (yellow) catenated by six others through its vertices. (c) The overall structure of the three-dimensional infinite polycatenated framework.

Figure 3 shows the SEM micrograph of catalyst 1 . It can be seen that the crystal of catalyst 1 has uniform positive octahedral structure. The macroscopic crystal structure is consistent with the microscopic positive octahedral cage structure.
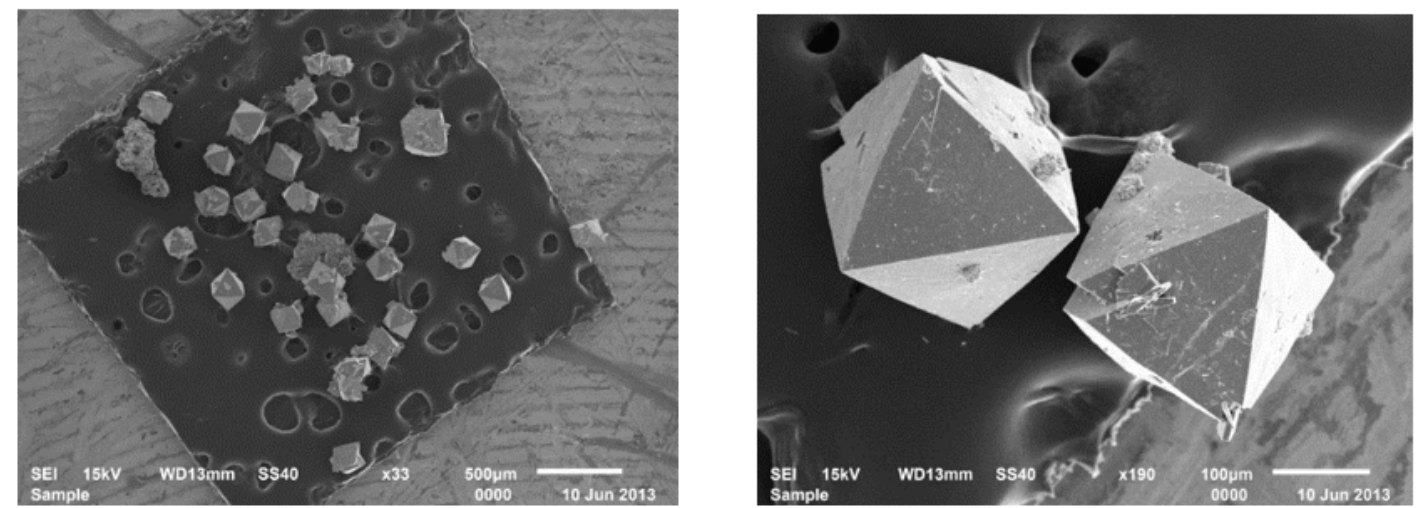

Figure 3. The SEM micrograph of catalyst 1.

The FT-IR spectrum of reference sample Ag-trz 3 is given in Figure 4. The peak at $1650 \mathrm{~cm}^{-1}$ belongs to the $-\mathrm{C}=\mathrm{N}$ - stretching vibration, and the two peaks appeared at $1147 \mathrm{~cm}^{-1}$ and $1062 \mathrm{~cm}^{-1}$ are attributed to the N-N stretching vibration in triazole ligand [25-28]. These results suggest that the structure of the triazole ring is well preserved in the reference sample Ag-trz ${ }_{3}$. Compared with the infrared spectrum of 1,2,4-triazole ligand (also shown in Figure 1), three new peaks appear at $2542 \mathrm{~cm}^{-1}$ and $2673 \mathrm{~cm}^{-1}$ and $2755 \mathrm{~cm}^{-1}$ in the infrared spectrum of Ag-trz ${ }_{3}$, while the two peaks belonging to 
the $>\mathrm{N}-\mathrm{H}$ stretching vibration at $3130 \mathrm{~cm}^{-1}$ and $1547 \mathrm{~cm}^{-1}$ disappear $[29,30]$. These changes should be an indication that triazole molecules are bonded with silver cations.

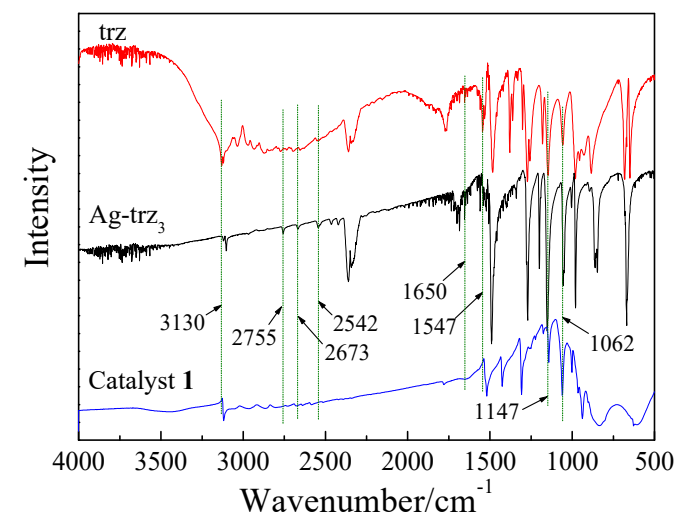

Figure 4. FT-IR spectra of fresh reference sample Ag-trz ${ }_{3}$ fresh 1,2,4-triazole and fresh catalyst 1.

\subsection{Catalytic Properties}

The catalytic performance of catalyst 1 and the reference samples of $\mathrm{Ag}-\mathrm{trz}_{3}, \mathrm{CH}_{3} \mathrm{COOAg}$ and PMA were investigated for the epoxidation of cis-cyclooctene and 1-octene with air as the oxidant and IBA as co-reagent. As shown in Table 1, all catalysts are active for the epoxidation of olefins with nearly $100 \%$ selectivity to the corresponding epoxides. Among these, catalyst 1 shows the highest activity. The result of cis-cyclooctene epoxidation by catalyst 1 exhibits that about $40 \%$ conversion is achieved after $1 \mathrm{~h}$ and the reaction is over after $3 \mathrm{~h}$ at the temperature of $40^{\circ} \mathrm{C}$. In comparison, the conversions of cis-cyclooctene by the reference samples of Ag-trz, $\mathrm{CH}_{3} \mathrm{COOAg}$ and PMA are much lower $(23 \%$, $51 \%$ and $5 \%$ conversions of cyclooctene after $3 \mathrm{~h}$, respectively). Notably, the pure PMA has very low catalytic activity under the tested conditions, while the $\mathrm{Ag}$ salts $\left(\mathrm{CH}_{3} \mathrm{COOAg}\right)$ and the related $\mathrm{Ag}$-trz 3 complex show moderate activity for the epoxidation of cyclooctene. These results suggest that silver species rather than PMA clusters are the main catalytically active sites for this reaction. Under the same reaction conditions, the reaction hardly proceed without a catalyst.

Table 1. Catalytic epoxidation of cyclooctene and 1-octene with $\mathrm{O}_{2} / \mathrm{IBA}$ over various catalysts ${ }^{\mathrm{a}}$.

\begin{tabular}{|c|c|c|c|c|c|}
\hline Catalyst & Substrate & Product & Time (h) & Conversion (\%) & Related work \\
\hline 1 & & & 3 & 96 & this work \\
\hline $\mathrm{Ag}-\operatorname{trz}_{3}$ & & & 3 & 23 & this work \\
\hline $\mathrm{CH} 3 \mathrm{COOAg}$ & & & 3 & 51 & this work \\
\hline PMA & & & 3 & 5 & this work \\
\hline $1^{b}$ & & & 2.5 & 94 & this work \\
\hline POM@MOF c & & & 4 & $95^{d}$ & Ref-31 \\
\hline 1 & & & 4 & 90 & this work \\
\hline Ag-trz 3 & & & 4 & 15 & this work \\
\hline $\mathrm{CH}_{3} \mathrm{COOAg}$ & & & 4 & 37 & this work \\
\hline PMA & & & 4 & 11 & this work \\
\hline POM@MOFc & & & 7 & $73^{d}$ & Ref-31 \\
\hline
\end{tabular}

a Reaction conditions: catalyst $10 \mathrm{mg}(0.001 \mathrm{mmol})$, substrate $1.0 \mathrm{mmol}, \mathrm{CH}_{3} \mathrm{CN} 10 \mathrm{ml}$, flow of air $10 \mathrm{~mL} / \mathrm{min}$, IBA $2.0 \mathrm{mmol}$, reaction temperature $40{ }^{\circ} \mathrm{C}$. All selectivities for the epoxide are $\geq 99 \%$. ${ }^{\mathrm{b}} \mathrm{CH}_{3} \mathrm{CN} 5 \mathrm{~mL}$. ${ }^{\mathrm{c}}\left[\mathrm{Ni}\left(4,4^{\prime} \text {-bpy }\right)_{2}\right]_{2} \cdot\left[\mathrm{V}^{\mathrm{IV}}{ }_{7} \mathrm{~V}^{\mathrm{V}}{ }_{9} \mathrm{O}_{38} \mathrm{Cl}\right] \cdot\left(4,4^{\prime}-\mathrm{bpy}\right) \cdot 6 \mathrm{H}_{2} \mathrm{O} .{ }^{\mathrm{d}}$ Reaction conditions: substrate $2.9 \mathrm{mmol}$, catalyst $0.02 \mathrm{mmol}$, IBA $5 \mathrm{mmol}, \mathrm{CH}_{3} \mathrm{CN} 5 \mathrm{~mL}$, air as oxidant at $35^{\circ} \mathrm{C}$.

Moreover, the reference samples Ag-trz $3 \mathrm{CH}_{3} \mathrm{COOAg}$ and PMA were obviously dissolved in the reaction mixture, revealing the homogeneous nature of these catalysts. By comparing with the related heterogeneous catalysts reported in literature work [31], we used less catalyst and isobutyraldehyde in the reaction, and also used a higher solvent dose. We therefore found that catalyst $\mathbf{1}$ has a much 
higher activity than the nickel-complex modified polyoxometalate catalyst in literature [31] for the epoxidation of cyclooctene with $\mathrm{O}_{2} / \mathrm{IBA}$ (Table 1 ).

In addition, the relatively inert terminal olefin of 1-octene can be also converted rapidly to the corresponding epoxide ( $90 \%$ conversion, nearly $100 \%$ epoxide selectivity after $4 \mathrm{~h}$ reaction) when 1 was used as catalyst. The activity of catalyst $\mathbf{1}$ is much higher than the other three reference samples.

These results proved that catalyst 1 not only exhibits much higher activity than reference sample Ag-trz, $\mathrm{CH}_{3} \mathrm{COOAg}$ and PMA, but also has efficient selectivity in the epoxidation reaction systems of several olefins.

The effect of solvents on the catalytic activity of 1 was also investigated by the epoxidation reaction of cyclooctene with air/IBA (Table 2). It can be seen that $\mathrm{CHCl}_{3}$-and $\mathrm{EtOH}$ - and $\mathrm{CH}_{3} \mathrm{CN}$ - mediated reactions give the increasing conversions in turn at $60^{\circ} \mathrm{C}$. These results suggest that the catalytic performance of catalyst 1 was solvent dependent [32]. According to the characteristics of the solvent, it can be inferred that the conversions is related to the polarity of the solvent. The bigger the polarity is, the more favorable the reaction is.

Table 2. Effect of solvents on the epoxidation of cyclooctene over catalyst 1.

\begin{tabular}{cccc}
\hline Entry & Solvent & Temperature $\left({ }^{\circ} \mathbf{C}\right)$ & Conversion (\%) \\
\hline 1 & $\mathrm{EtOH}$ & 60 & 64 \\
2 & $\mathrm{CHCl}$ & 60 & 62 \\
3 & $\mathrm{CH}_{3} \mathrm{CN}$ & 25 & 81 \\
4 & $\mathrm{CH}_{3} \mathrm{CN}$ & 35 & 89 \\
5 & $\mathrm{CH}_{3} \mathrm{CN}$ & 40 & 96 \\
6 & $\mathrm{CH}_{3} \mathrm{CN}$ & 60 & 98
\end{tabular}

Reaction conditions: catalyst $10 \mathrm{mg}(0.001 \mathrm{mmol})$, cyclooctene $1.0 \mathrm{mmol}$, solvent $10 \mathrm{ml}$, flow of air $10 \mathrm{ml} / \mathrm{min}$, IBA $2.0 \mathrm{mmol}$, time $=3 \mathrm{~h}$. All selectivities for the epoxide are $\geq 99 \%$.

Using $\mathrm{CH}_{3} \mathrm{CN}$ as solvent, the temperature effect on the catalytic performance was also studied (Table 2, entries 3-6). "Green" in consideration of reaction conditions, the optimum temperature of the reaction is $40^{\circ} \mathrm{C}$.

In addition, the catalytic properties of catalyst 1 were also investigated for the epoxidation of other olefins. As shown in Table 3, relatively high activity and expoxide selectivity could be achieved for the epoxidation cyclohexene and styrene at mild reaction conditions. In particularly, this catalyst could also efficiently convert the bulky molecular of cyclododecene to the corresponding epoxide, with $82 \%$ conversion and $99 \%$ selectivity of epoxide at $61{ }^{\circ} \mathrm{C}$ after $6 \mathrm{~h}$ reaction. These results illustrate that catalyst 1 is highly efficient for the $\mathrm{O}_{2} /$ IBA-mediated epoxidation of a large scope of olefins.

Table 3. Epoxidation of Various Substrates with $\mathrm{O}_{2}$ in Air Catalyzed by catalyst 1.

\begin{tabular}{lcccccc}
\hline Entry & Substrate & $\begin{array}{c}\text { Temperature } \\
\left({ }^{\circ} \mathbf{C}\right)\end{array}$ & $\begin{array}{c}\text { Time } \\
(\mathbf{h})\end{array}$ & $\begin{array}{c}\text { Conversion } \\
(\mathbf{\%})\end{array}$ & \multicolumn{2}{c}{ Selectivity (\%) } \\
\cline { 5 - 7 } & 35 & 3 & 96 & 84 & 16 \\
\hline
\end{tabular}

Reaction conditions: catalyst $10 \mathrm{mg}(0.001 \mathrm{mmol})$, substrate $1.0 \mathrm{mmol}, \mathrm{CH}_{3} \mathrm{CN} 10 \mathrm{ml}$, flow of air $10 \mathrm{ml} / \mathrm{min}$, IBA $2.0 \mathrm{mmol}$.

To verify the heterogeneity of the catalytic process, a leaching test was performed for the epoxidation of cis-cyclooctene and 1-octene over the catalyst 1 . As shown in Figure 5, catalyst 1 shows 
very high stability against leaching of the active species. Besides, catalyst $\mathbf{1}$ can be easily recovered from the reaction system by filtration. The recovered solid could be reused directly as catalyst for the next run after washing with water. Catalyst 1 can be reused for at least ten cycles without significant change of conversions, proving that this system has persistent activity during the recycling experiments (Figure 6). These results suggested that the metal-organic polycatenation is truly heterogeneous catalyst under the reaction conditions employed. The high structural stability of catalyst $\mathbf{1}$ might be mainly attributed to the formation of the hybrid framework based on the Ag-triazole framework and the PMA clusters, and the relatively strong interaction between them.

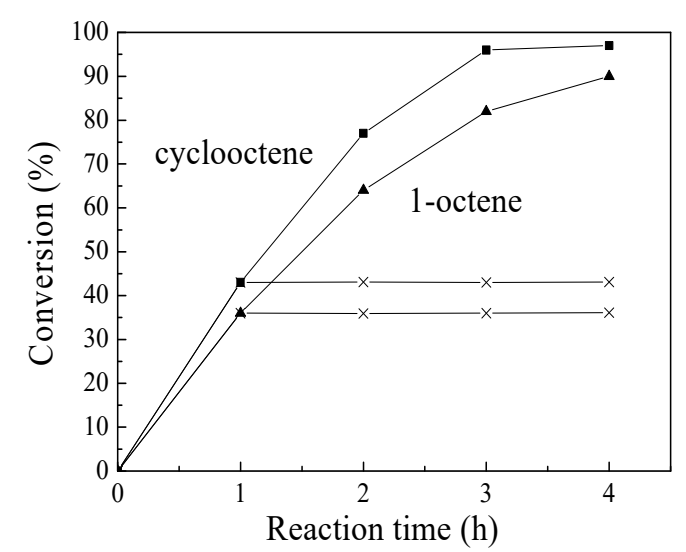

Figure 5. Kinetic profiles of the epoxidation of cyclooctene and 1-octene over the catalyst 1. (x) Leaching experiments of the catalyst indicating conversion of cyclooctene and 1-octene with the catalyst removed after $4 \mathrm{~h}$ at reaction temperature. Reaction conditions: catalyst $10 \mathrm{mg}$, substrate $1.0 \mathrm{mmol}, \mathrm{CH}_{3} \mathrm{CN}$ $10 \mathrm{~mL}$, flow of air $10 \mathrm{~mL} / \mathrm{min}$, IBA $2.0 \mathrm{mmol}$, reaction temperature $40^{\circ} \mathrm{C}$. All selectivities for the epoxide are $\geq 99 \%$.

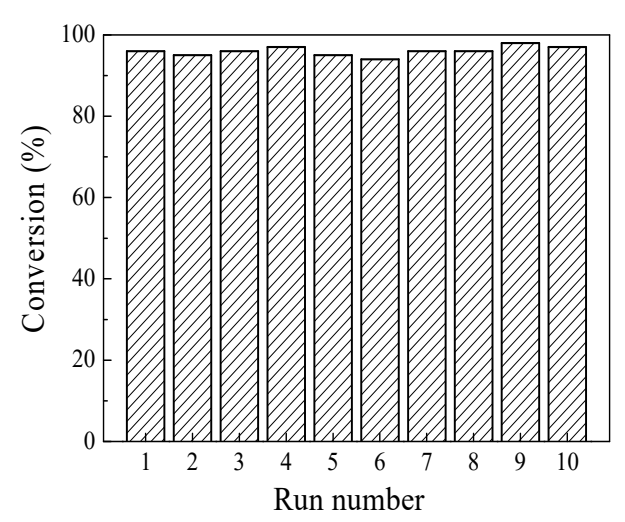

Figure 6. Recycling experiments of catalyst 1 for epoxidation of cis-cyclooctene with air/IBA. Reaction conditions: catalyst $10 \mathrm{mg}$, cis-cyclooctene $1.0 \mathrm{mmol}, \mathrm{CH}_{3} \mathrm{CN} 10 \mathrm{~mL}$, flow of air $10 \mathrm{~mL} / \mathrm{min}$, IBA $2.0 \mathrm{mmol}$, reaction temperature $40{ }^{\circ} \mathrm{C}$, reaction time $3 \mathrm{~h}$. All selectivities for the epoxide are $\geq 99 \%$.

For oxidation/epoxidation reaction, utilization efficiency of sacrificial reductant and material balance is shown in Table S1. In addition, the typical GC charts are shown in supplementary materials.

FT-IR and XRD measurements were carried out to investigate the structural stability of catalyst 1. The FT-IR spectra show that there is no obvious difference between the used catalysts (after the reaction of cyclooctene and 1-octene epoxidations) and the fresh one (Figure 7). The XRD patterns indicate that the characteristic diffraction peaks for the used catalysts are consistent with the fresh catalyst $\mathbf{1}$ (Figure 8). These results suggested that the structure of catalyst $\mathbf{1}$ is kept well during the reaction process. 


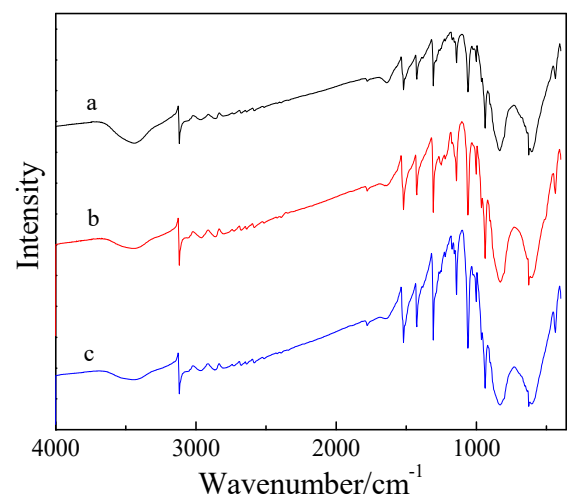

Figure 7. FT-IR spectra of fresh catalyst $\mathbf{1}$ (a) and used one in cyclooctene epoxidation (b) and used one in 1-octene epoxidation (c).

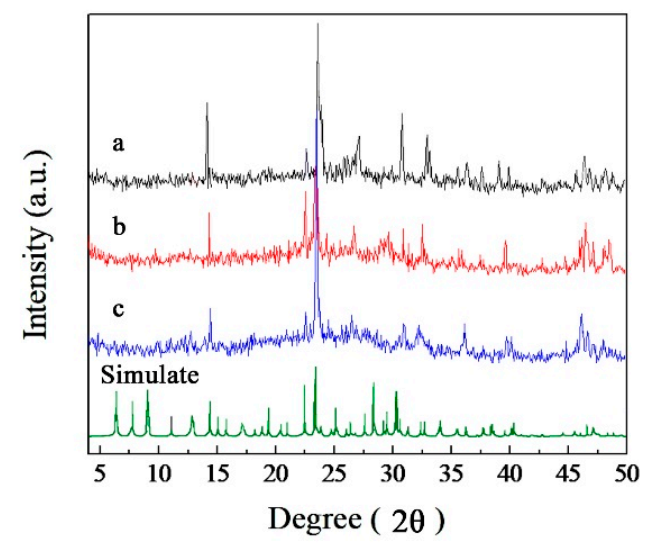

Figure 8. XRD patterns of fresh catalyst $\mathbf{1}$ (a), used one in cyclooctene epoxidation (b), used one in 1-octene epoxidation (c) and the simulated pattern.

The XPS measurements were carried out for various samples. Figure 9 shows the $\mathrm{Ag} 3 \mathrm{~d}$ spectra of catalyst 1, Ag-trz 3 and $\mathrm{CH}_{3} \mathrm{COOAg}$. There are two major peaks of $\mathrm{Ag} 3 \mathrm{~d}$, assigned to $\mathrm{Ag} 3 \mathrm{~d} 5 / 2$ at $368.55 \mathrm{eV}$ and $\mathrm{Ag} 3 \mathrm{~d} 3 / 2$ at $374.6 \mathrm{eV}$ photoelectrons, respectively, indicating that $\mathrm{Ag}$ species existed in the form of $\mathrm{Ag}^{+}[29,33-38]$. The Ag BE values for catalyst 1 shift positively compared with other samples, which can be assigned to the charge interaction between PMA ions and silver cations.

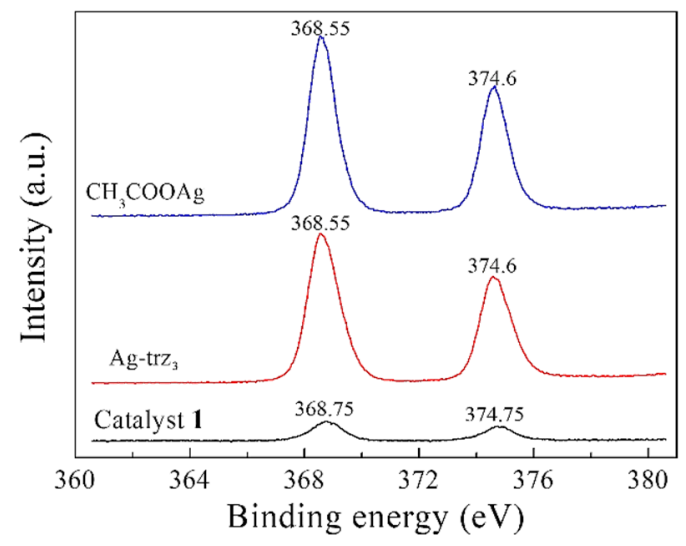

Figure 9. X-ray photoelectron $\mathrm{Ag} 3 \mathrm{~d}$ spectra of catalyst $1, \mathrm{Ag}-\mathrm{trz}_{3}$ and $\mathrm{CH}_{3} \mathrm{COOAg}$.

The XPS spectra of N 1s is shown in Figure 10. For trz and Ag-trz 3 , the appearance of binding energies at $399.7 \mathrm{eV}$ is attributed to the $\mathrm{N} 1 \mathrm{~s}$ of $=\mathrm{N}$ - or $-\mathrm{NH}$ - on triazole ring [39-41]. Compared with triazole, the binding energies of $\mathrm{N} 1 \mathrm{~s}$ in the catalyst 1 shift positively (from $399.7 \mathrm{eV}$ to $399.85 \mathrm{eV}$ ), 
suggesting that relatively strong coordinative interaction is present between $\mathrm{Ag}^{+}$and triazole ligands in this catalyst.

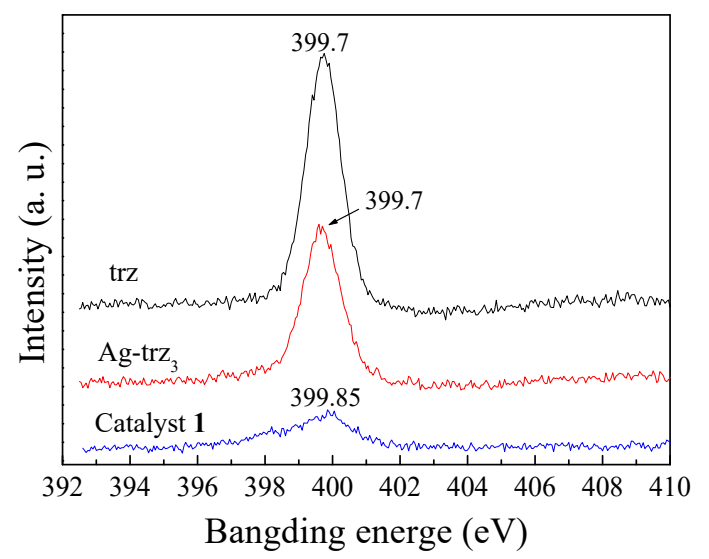

Figure 10. X-ray photoelectron N1 spectra of catalyst 1, Ag-trz 3 and trz.

Figure 11 shows the Mo $3 \mathrm{~d}$ spectra of PMA and catalyst 1 . For PMA, the Mo $3 \mathrm{~d}$ spectrum is deconvoluted into one doublet Mo3d5/2 at $233.3 \mathrm{eV}$ and Mo3d $3 / 2$ at $236.5 \mathrm{eV}$, which is attributed to the Mo6+ oxidation state [42-44]. After introducing the PMA into the infinite three-dimensional polycatenated framework, the Mo3d peaks shift slightly toward lower binding energies (Mo3d5/2 at $232.75 \mathrm{eV}$ and Mo3d $3 / 2$ at $235.85 \mathrm{eV}$ ), further reflecting the presence of interaction between PMA units and the polycatenated framework.

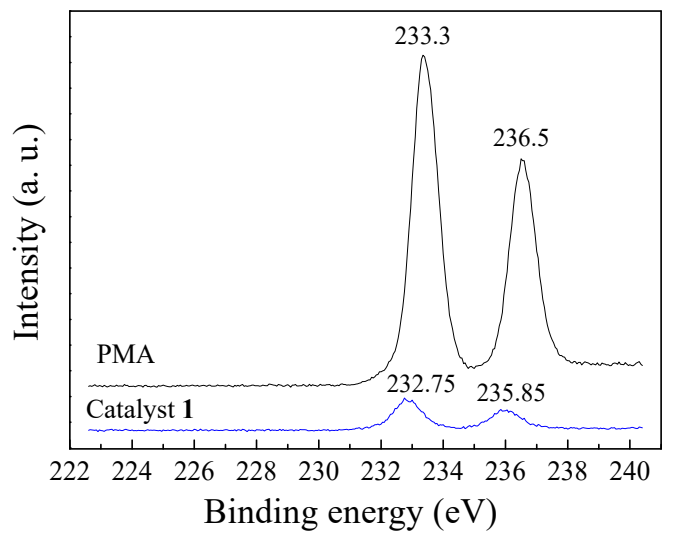

Figure 11. X-ray photoelectron Mo3d spectra of PMA and catalyst 1.

In general, the polycatenane compounds have a relatively large open framework, which is suitable for the diffusion of the reactants to increase the substrate contact with the catalyst active sites, thus helping to improve the catalytic activity $[31,42,44]$. Meanwhile, the formation of multidimensional supramolecular structure through multiple weak interactions, such as charge interaction and hydrogen bonds, should be very critical in fabricating highly efficient and stable POM-based catalysts [12,42,45]. In our case, the relatively high stability of the catalysts 1 should be mainly due to the following reasons. First, the infinite three-dimensional polycatenated framework consisting of $\mathrm{Ag}^{+}$and 1,2,4-triazole ligand could effectively inhibit the aggregation of PMA clusters by space limitation. Second, the abundant electron-rich terminal oxygen atoms of PMA anions and the $\mathrm{Ag}^{+}$cations located in the whole 3-D framework can result in the formation of multi-interactions. In another word, the $\mathrm{Ag}^{+}$atoms existed in the 3-D framework can produce electrostatic interaction with the PMA anion from different directions, thus being beneficial to the formation of a highly stable PMA-based catalyst. 
For the aerobic oxidation of olefin in the presence of IBA, it is believed that the epoxidation reaction may follow acylperoxy radicals (formed in autoxidation) or alkylperoxy radicals (formed in cooxidation process). In general, cooxidation affords yields of epoxides that are much higher than those obtained from the autoxidation of the olefin alone, since acylperoxy radicals are more selective than alkylperoxy radicals in favoring addition relative to abstraction [46-51]. Therefore, it seems reasonable to propose that the epoxidation of olefins over catalyst 1 should be mainly follow a cooxidation mechanism of aldehydes and olefins. This is shown in Scheme 1. The first step of the reaction should involve the adsorption/activation process of IBA on catalyst $\mathbf{1}$, to generate carbon-center free radicals of RCO . Subsequently, it reacts with the surface adsorbed $\mathrm{O}_{2}$ to produce acylperoxy radicals $\left(\mathrm{RCO}_{3} \cdot\right)$. After that, $\mathrm{RCO}_{3}$. could either react directly with olefin to get epoxides and $\mathrm{RCOOH}$, or interact with IBA to form $\mathrm{RCO} \bullet$ and $\mathrm{RCO}_{3} \mathrm{H}$, which is another active intermediate for the epoxidation of olefin.

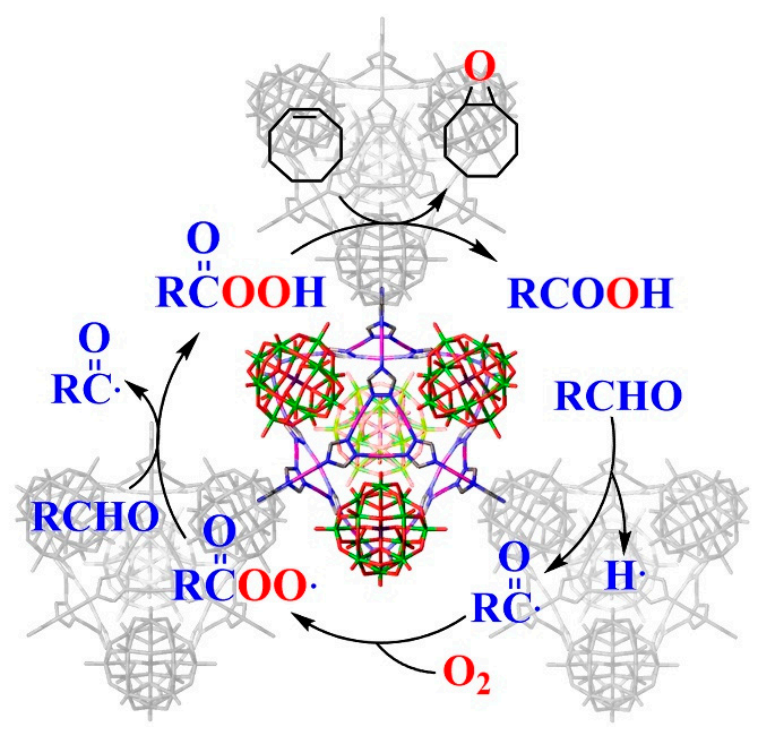

Scheme 1. Proposed mechanism for epoxidation of olefins on catalyst $\mathbf{1}$.

\section{Materials and Methods}

\subsection{Synthesis of the Catalysts}

\subsubsection{Synthesis of $\left\{\left[\mathrm{Ag}_{2}(\operatorname{trz})_{2}\right]\left[\mathrm{Ag}_{24}(\operatorname{trz})_{18}\right]\right\}\left[\mathrm{PMo}_{12} \mathrm{O}_{40}\right]_{2}(1)$}

$\mathrm{CH}_{3} \mathrm{COOAg}(0.1001 \mathrm{~g}, 1 \mathrm{mmol}), \mathrm{H}_{3} \mathrm{PMo}_{12} \mathrm{O}_{40}(0.3651 \mathrm{~g}, 0.2 \mathrm{mmol}), 1,2,4$-triazole $(0.1392 \mathrm{~g}, 2.0 \mathrm{mmol})$ and water $(15 \mathrm{~mL})$ were added in succession. After stirring the mixture $(\mathrm{pH}=4)$ for $1 \mathrm{~h}$ at room temperature, it was sealed in a $25 \mathrm{~mL}$ Teflon-lined autoclave and heated at $160^{\circ} \mathrm{C}$ for $96 \mathrm{~h}$, followed by cooling to room temperature with a rate of $10{ }^{\circ} \mathrm{C} \cdot \mathrm{h}^{-1}$. Light green block type crystals, being suitable for X-ray analysis, were collected. The entire yield is $81 \%$ based on Mo. The CCDC number of catalyst 1 is 873140 .

\subsubsection{Reference Sample Ag-trz}

For comparison, the silver complex derived from $\mathrm{CH}_{3} \mathrm{COOAg}$ and 1,2,4-triazole ligand was synthesized under the similar hydrothermal condition, just without the addition of PMA. Some white powder microcrystals were obtained with a $55 \%$ yield based on $\mathrm{Ag}$. The resultant complex is denoted as $\mathrm{Ag}-\mathrm{trz}_{3}$, in which the mole ratio of $\mathrm{Ag} / \mathrm{trz}$ is determined by elemental analysis.

\subsection{Materials and Methods}

$\mathrm{CH}_{3} \mathrm{COOAg}(\geq 99 \%), \mathrm{H}_{3} \mathrm{PMo}_{12} \mathrm{O}_{40}(\geq 99 \%)$, 1, 2, 4-triazole (trz, $\geq 99 \%$ ), cis-cyclooctene (95\%), 1-octene (95\%), chloroform ( $\geq 99 \%)$, acetonitrile ( $\geq 99 \%, A R)$, ethanol ( $\geq 99.7 \%, A R)$ and isobutyraldehyde (IBA) were obtained commercially (aladdin-e Inc., Shanghai, China) and used without additional purification. 
FT-IR spectra were recorded on a Nicolet AVATAR 370 DTGS spectrometer (Thermo Electron (Shanghai) Instruments Co., Shanghai, China) in the range $400-4000 \mathrm{~cm}^{-1}$. FT-IR $\left(\mathrm{KBr}, 4000-400 \mathrm{~cm}^{-1}\right)$ of catalyst 1: 3116(s), 1778(m), 1635(m), 1517(s), 1425(s), 1307(s), 1140(s), 1053(s), 934(m), 831(w), 626(w), 435(w).

Elemental analyses of (C, H and N) were carried out with a Vario EL III elemental analyzer. Elemental analyses of Ag and Mo were carried out with a 2100DV ICP-AES spectrometer. Elemental analysis (\%) calcd for $\mathrm{C}_{40} \mathrm{H}_{40} \mathrm{~N}_{60} \mathrm{O}_{80} \mathrm{Ag}_{26} \mathrm{P}_{2} \mathrm{Mo}_{24}$ (catalyst 1 formula weight = 7809.08): $\mathrm{Ag} 35.91$, Mo 29.49, C 6.15, H 0.51, N 10.76; found: Ag 35.89, Mo 29.54, C 6.22, H 0.44, N 10.73. There are no water molecules exist.

Powder X-ray diffraction (XRD) measurements were performed on a Shimadzu XRD-6000 diffractometer (40 kV, $30 \mathrm{~mA}$ ) (Shimadzu (Shanghai) Global Laboratory Consumables Co., Ltd., Shanghai, China) using Ni-filtered $\mathrm{Cu}-\mathrm{K} \alpha$ radiation in the angular range $2 \theta=5^{\circ}-50^{\circ}$ at $293 \mathrm{~K}$. SEM measurements were performed on JSM-6510 Series Scanning Electron Microscope.

Intensity data were measured on a Siemens SMART CCD (SLC Changchun Branch, Changchun, China) with graphite-monochromatized Mo-K $\alpha$ radiation $(\lambda=0.71073 \AA)$ at $293 \mathrm{~K}$ and corrected for adsorption by the SADABS program [52]. The structure of the crystal was solved by direct method and refined by full-matrix least-squares method with the SHELXL-97 program package [53]. The hydrogen atoms attached to carbon positions were placed in geometrically calculated positions.

\subsection{Catalyst Test}

The catalytic oxidation reaction was carried out in a $50 \mathrm{~mL}$ three-necked bottle equipped with a stirring bar, reflux condenser, and gas supply. Solvent, olefin, IBA and catalyst were added into the flask respectively, and the whole device was placed in a temperature-controlled oil bath. All catalysts were ground into powder in a mortar, which is then put into the reaction system. To commence the reaction, oxygen was passed through the reactor at a flow rate of $10 \mathrm{ml} / \mathrm{min}^{-1}$ under atmosphere. The oxidation products of the reaction were analyzed and quantified by Shimadzu GC-8A gas chromatograph (Shimadzu (Shanghai) Global Laboratory Consumables Co., Ltd., Shanghai, China) with an HP-5 capillary column.

\section{Conclusions}

A metal-organic polycatenated compound based on PMA and Ag-triazole complexes was synthesized in a very simple and efficient way. This compound showed excellent catalytic activity and selectivity for the aerobic Mukaiyama epoxidation of olefins as a catalyst. Combined with the characteristics of the structure, we can see that the supramolecular structure is a very open framework, which is suitable for the diffusion of the reactants to increase the substrate contact with the catalyst active sites, thus helping to improve the catalytic activity. This catalyst is heterogeneous in nature and can be easily recycled without a decrease in activity. This shows that catalyst $\mathbf{1}$ has very excellent stability. This result also indicates that weak interactions such as non-covalent mechanical interactions and weak interactions should be critical for the stability of the catalyst.

Supplementary Materials: The following are available online at http://www.mdpi.com/2073-4344/9/7/568/s1, Figure S1 The GC spectrogram of 1-octene. Figure S2 The GC spectrogram of cyclooctene. Figure S3 The crystal cell structrue of catalyst 1 . Figure $\mathrm{S} 4$ The 2D frameworks form a three-dimensional polycatenaned framework through interlocking of vertex angles. Table S1. Catalytic epoxidation of cyclooctene and 1-octene with $\mathrm{O}_{2} / \mathrm{IBA}$ over catalyst 1 . Table S2 Crystal data and structure refinement of catalyst 1 .

Author Contributions: Conceptualization, J.D.; Data curation, X.L.; Formal analysis, G.C. and M.J.; Funding acquisition, Y.L. and M.J.; Investigation, X.L. and J.Z.; Methodology, J.D. and E.Z.; Project administration, J.D.; Resources, Y.L.; Supervision, G.C.; Writing—original draft, J.D.; Writing—review \& editing, M.J.

Acknowledgments: This work was financially supported by the National Natural Science Foundation of China (Grant Nos. 21173100, 21703078).

Conflicts of Interest: The authors declare no conflict of interest. 


\section{References}

1. Roy, S.; Vemuri, V.; Maiti, S.; Manoj, K.S.; Subbarao, U.; Peter, S.C. Two Keggin-Based Isostructural POMOF Hybrids: Synthesis, Crystal Structure, and Catalytic Properties. Inorg. Chem. 2018, 57, 12078-12092. [CrossRef] [PubMed]

2. Li, X.; Zhou, K.F.; Tong, Z.B.; Yang, J.B.; Sheng, N.; Li, J.S.; Sha, J.Q. Keggin polyoxometalates based hybrid compounds containing helix/nanocages for colorimetric biosensing. J. Solid State Chem. 2018, 265, 372-380. [CrossRef]

3. Jiang, W.; Chen, L.; Cheng, W.W.; Dong, Y.Y.; Gong, J.J.; Shen, H.C.; Xu, Y. Three hybrid tungstosilicates: Confinement of $\mathrm{SiW}_{12} \mathrm{O}_{40}{ }^{4-}$ anions in rigid concave surfaces with excellent nonlinear optical performance and interesting magnetic properties. Polyhedron 2018, 151, 185-191. [CrossRef]

4. Tian, P.; He, X.; Li, W.X.; Zhao, L.; Fang, W.; Chen, H.; Zhang, F.Q.; Zhang, W.Q.; Wang, W. Zr-MOFs based on Keggin-type polyoxometalates for photocatalytic hydrogen production. J. Mater. Sci. 2018, 53, 12016-12029. [CrossRef]

5. Kaczmarek, A.M. Eu ${ }^{3+} / \mathrm{Tb}^{3+}$ and $\mathrm{Dy}^{3+} \mathrm{POM} @ \mathrm{MOF}$ and 2D coordination polymers based on pyridine-2, 6-dicarboxylic acid for ratiometric optical temperature sensing. J. Mater. Chem. C 2018, 6, 5916-5925. [CrossRef]

6. Sha, J.Q.; Li, X.; Li, J.S.; Yang, X.Y.; Zhang, H.F.; Yue, M.B.; Zhou, K.F. Acidity Considerations in the Self-Assembly of POM/Ag/trz-Based Compounds with Efficient Electrochemical Activities in LIBs. Cryst. Growth Des. 2018, 18, 2289-2296. [CrossRef]

7. Wang, X.L.; Zhao, D.; Tian, A.X.; Ying, J. Three 3D silver-bis(triazole) metal-organic frameworks stabilized by high-connected Wells-Dawson polyoxometallates. Dalton Trans. 2014, 43, 5211-5220. [CrossRef]

8. Ying, J.; Chen, Y.G.; Wang, X.Y. A series of OD to 3D Anderson-type polyoxometalate-based compounds obtained under ambient and hydrothermal conditions. CrystEngComm 2019, 21, 1168-1179. [CrossRef]

9. Somayeh, T.; Masoud, M.; Hossein, E.H.; Antonio, F. Tuning the topology of hybrid inorganic-organic materials based on the study of flexible ligands and negative charge of polyoxometalates: A crystal engineering perspective. Coord. Chem. Rev. 2016, 309, 84-106.

10. Hao, X.L.; Jia, S.F.; Ma, Y.Y.; Wang, H.Y.; Li, Y.G. Two new Keggin-type polyoxometalate-based entangled coordination networks constructed from metal-organic chains with dangling arms. Inorg. Chem. Commun. 2016, 72, 132-137. [CrossRef]

11. Bai, X.; Lin, H.Y.; Sun, J.J.; Liu, G.C.; Wang, X.; Wang, X.L. Two Anderson-type polyoxometalate-induced various Co-complexes based on a rigid pyrazine-bis(triazole) ligand. Inorg. Chem. Commun. 2018, 92, 151-156. [CrossRef]

12. Song, X.J.; Yan, Y.; Wang, Y.N.; Hu, D.W.; Xiao, L.N.; Yu, J.H.; Zhang, W.X.; Jia, M.J. Hybrid compounds assembled from copper-triazole complexes and phosphomolybdic acid as advanced catalysts for the oxidation of olefins with oxygen. Dalton Trans. 2017, 46, 16655-16662. [CrossRef] [PubMed]

13. Liu, B.; Yang, J.; Yang, G.C.; Ma, J.F. Four New Three-Dimensional Polyoxometalate-Based Metal-Organic Frameworks Constructed From $\left[\mathrm{Mo}_{6} \mathrm{O}_{18}\left(\mathrm{O}_{3} \mathrm{AsPh}\right)_{2}\right]^{4-}$ Polyoxoanions and Copper(I)-Organic Fragments: Syntheses, Structures, Electrochemistry, and Photocatalysis Properties. Inorg. Chem. 2013, 52, 84-94. [CrossRef] [PubMed]

14. Shi, Z.Y.; Gu, X.J.; Peng, J.; Yu, X.; Wang, E.B. From Molecular Double-Ladders to an Unprecedented Polycatenation: A Parallel Catenated 3D Network Containing Bicapped Keggin Polyoxometalate Clusters. Eur. J. Inorg. Chem. 2006, 2, 385-388. [CrossRef]

15. Wang, X.L.; Lin, H.Y.; Bi, Y.F.; Chen, B.K.; Liu, G.C. An unprecedented extended architecture constructed from a 2-D interpenetrating cationic coordination framework templated by $\mathrm{SiW}_{12} \mathrm{O}_{40}{ }^{4-}$ anion. J. Solid State Chem. 2008, 181, 556-561. [CrossRef]

16. Du, X.D.; Li, C.H.; Zhang, Y.; Liu, S.; Ma, Y.; You, X.Z. Coordination polymers based on the octamolybdate and flexible bis(triazole) ligands with different spacer lengths. CrystEngComm 2011, 13, 2350-2357. [CrossRef]

17. Kuang, X.F.; Wu, X.Y.; Yu, R.M.; Donahue, J.P.; Huang, J.S.; Lu, C.Z. Assembly of a metal-organic framework by sextuple intercatenation of discrete adamantine-like cages. Nat. Chem. 2010, 2, 461-465. [CrossRef]

18. Sha, J.Q.; Li, M.T.; Yang, X.Y.; Sheng, N.; Li, J.S.; Zhu, M.L.; Liu, G.D.; Jiang, J.Z. New Route toward POM[6]Catenane Members for Lithium-Ion Batteries. Cryst. Growth Des. 2017, 17, 3775-3782. [CrossRef] 


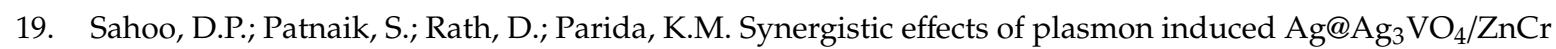
$\mathrm{LDH}$ ternary heterostructures towards visible light responsive $\mathrm{O}_{2}$ evolution and phenol oxidation reactions. Inorg. Chem. Front. 2018, 5, 879-896. [CrossRef]

20. Cao, L.J.; Tao, P.P.; Li, M.C.; Lyu, F.C.; Wang, Z.Y.; Wu, S.S.; Wang, W.X.; Huo, Y.F.; Huang, L.; Lu, Z.G. Synergistic Effects of $\mathrm{C} / \alpha-\mathrm{MoC}$ and Ag for Efficient Oxygen Reduction Reaction. J. Phys. Chem. Lett. 2018, 9 , 779-784. [CrossRef]

21. Laura, M.; Jiménez, D.; Luis, A.P. Molecular oxygen adsorption and dissociation on $\mathrm{Au}_{12} \mathrm{M}$ clusters with $\mathrm{M}=\mathrm{Cu}, \mathrm{Ag}$ or Ir. Eur. Phys. J. D 2018, 72, 51-60.

22. Luo, W.W.; Liu, G.; Wang, X.; Lei, X.L.; Ouyang, C.Y.; Liu, S.Q. The adsorption and dissociation of oxygen on Ag (111) supported $\chi 3$ borophene. Phys. B Condens. Matter 2018, 537, 1-6. [CrossRef]

23. Wu, Y.S.; Yuan, S.S.; Feng, R.; Ma, Z.C.; Gao, Y.Z.; Xing, S.T. Comparative study for low-temperature catalytic oxidation of o-xylene over doped OMS-2 catalysts: Role of Ag and Cu. Mol. Catal. 2017, 442, $164-172$. [CrossRef]

24. Li, Y.F.; Liu, F.F.; Fan, Y.; Cheng, G.; Song, W.; Zhou, J.L. Silver palladium bimetallic core-shell structure catalyst supported on $\mathrm{TiO}_{2}$ for toluene oxidation. Appl. Surf. Sci. 2018, 462, 207-212. [CrossRef]

25. Gümüs, M.K.; Kansız, S.; Aydemir, E.; Gorobets, N.Y.; Dege, N. Structural features of 7-methoxy-5-methyl2-(pyridin-3-yl)-11,12-dihydro-5,11-methano[1,2,4] triazolo[1,5-c][1,3,5]benzoxadiazocine: Experimental and theoretical (HF and DFT) studies, surface properties (MEP, Hirshfeld). J. Mol. Struct. 2018, 1168, $280-290$. [CrossRef]

26. Jin, R.Y.; Zeng, C.Y.; Liang, X.H.; Sun, X.H.; Liu, Y.F.; Wang, Y.Y.; Zhou, S. Design, synthesis, biological activities and DFT calculation of novel 1,2,4-triazole Schiff base derivatives. Bioorganic Chem. 2018, 80, 253-260. [CrossRef]

27. Calu, L.; Badea, M.; Korošin, N.Č.; Chifiriuc, M.C.; Bleotu, C.; Stanică, N.; Silvestro, L.; Maurer, M.; Olar, R. Spectral, thermal and biological characterization of complexes with a Schiff base bearing triazole moiety as potential antimicrobial species. J. Therm. Anal. Calorim. 2018, 134, 1839-1850. [CrossRef]

28. Aouad, M.R.; Messali, M.; Rezki, N.; Zaqri, N.A.; Warad, I. Single proton intramigration in novel 4-phenyl-3-((4-phenyl-1H-1,2,3-triazol-1-yl)methyl)-1H-1,2,4-triazole-5(4H)-thione: XRD-crystal interactions, physicochemical, thermal, Hirshfeld surface, DFT realization of thiol/thione tautomerism. J. Mol. Liq. 2018, 264, 621-630. [CrossRef]

29. Vinita; Tiwari, M.; Prakash, R. Colorimetric detection of picric acid using silver nanoparticles modified with 4-amino-3-hydrazino-5-mercapto-1, 2, 4-triazole. Appl. Surf. Sci. 2018, 449, 174-180. [CrossRef]

30. Dudley, H.W.; Lan, F. Spectroscopic Methods in Organic Chemistry; Mcgraw-Hill: London, UK, 1966; Volume 222, price 38s.

31. Wang, S.; Liu, Y.W.; Zhang, Z.; Li, X.H.; Tian, H.R.; Yan, T.T.; Zhang, X.; Liu, S.; Sun, X.W.; Xu, L.; et al. One-Step Template-Free Fabrication of Ultrathin Mixed-Valence Polyoxovanadate-Incorporated Metal-Organic Framework Nanosheets for Highly Efficient Selective Oxidation Catalysis in Air. ACS Appl. Mater. Interfaces 2019. [CrossRef]

32. Wang, J.; Zou, Y.C.; Sun, Y.; Hemgesberg, M.; Schaffner, D.; Gao, H.C.; Song, X.J.; Zhang, W.X.; Jia, M.J.; Thiel, W.R. Electrostatic immobilization of phosphomolybdic acid on imidazolium-based mesoporous organosilicas for catalytic olefin epoxidation. Chin. J. Catal. 2014, 35, 532-539. [CrossRef]

33. Huang, Y.; Zhang, X.Y.; Zhu, G.X.; Gao, Y.J.; Cheng, Q.F.; Cheng, X.W. Synthesis of silver phosphate/sillenite bismuth ferrite/graphene oxide nanocomposite and its enhanced visible light photocatalytic mechanism. Sep. Purif. Technol. 2019, 215, 490-499. [CrossRef]

34. Feng, Z.Z.; Yu, J.J.; Sun, D.P.; Wang, T.H. Visible-light-driven photocatalysts Ag/AgCl dispersed on mesoporous $\mathrm{Al}_{2} \mathrm{O}_{3}$ with enhanced photocatalytic performance. J. Colloid Interface Sci. 2016, 480, $184-190$. [CrossRef] [PubMed]

35. Nagaraju, P.; Hafedh, D.; Mohammed, R.A.R.; Abdulrahim, A.A.Z.; Muhammad, A.D.; Arshid, M.A.; Sharif, F.Z.; Lachezar, A.P. Methanol Synthesis Using $\mathrm{CO}_{2}$ and $\mathrm{H}_{2}$ on Nano Silver-Ceria Zirconia Catalysts: Influence of Preparation Method. J. Nanosci. Nanotechnol. 2019, 19, 3197-3204.

36. Gambardella, A.; Berni, M.; Graziani, G.; Kovtun, A.; Liscio, A.; Russo, A.; Visani, A.; Bianchi, M. Nanostructured Ag thin films deposited by pulsed electron ablation. Appl. Surf. Sci. 2019, 475, 917-925. [CrossRef] 
37. Ji, X.B.; Chen, Y.X.; Paul, B.; Vadivel, S. Photocatalytic oxidation of aromatic alcohols over silver supported on cobalt oxide nanostructured catalyst. J. Alloy. Compd. 2019, 783, 583-592. [CrossRef]

38. Raghunath, D.; Venkata, S.S.; Hugues, K.P.; Madhumita, B.; Vinesh, M.; Arjun, M. Silver decorated magnetic nanocomposite $\left(\mathrm{Fe}_{3} \mathrm{O}_{4} @ \mathrm{PPy}-\mathrm{MAA} / \mathrm{Ag}\right)$ as highly active catalyst towards reduction of 4-nitrophenol and toxic organic dyes. Appl. Catal. B Environ. 2019, 244, 546-558.

39. Matjaž, F. EQCM and XPS analysis of 1, 2, 4-triazole and 3-amino-1, 2, 4-triazole as copper corrosion inhibitors in chloride solution. Corros. Sci. 2013, 77, 350-359.

40. Yang, L.Y.; Xin, L.L.; Gu, W.; Tian, J.L.; Liao, S.Y.; Du, P.Y.; Tong, Y.Z.; Zhang, Y.P.; Lv, R.; Wang, J.Y.; et al. A new carboxyl-copper-organic framework and its excellent selective absorbability for proteins. J. Solid State Chem. 2014, 218, 64-70. [CrossRef]

41. Bentiss, F.; Traisnel, M.; Gengembre, L.; Lagrenée, M. A new triazole derivative as inhibitor of the acid corrosion of mild steel: Electrochemical studies, weight loss determination, SEM and XPS. Appl. Surf. Sci. 1999, 152, 237-249. [CrossRef]

42. Gao, W.X.; Sun, X.Y.; Niu, H.L.; Song, X.J.; Li, K.G.; Gao, H.C.; Zhang, W.X.; Yu, J.H.; Jia, M.J. Phosphomolybdic acid functionalized covalent organic frameworks: Structure characterization and catalytic properties in olefin epoxidation. Microporous Mesoporous Mater. 2015, 213, 59-67. [CrossRef]

43. Zhang, H.Y.; Miao, A.J.; Jiang, M. Fabrication, characterization and electrochemistry of organice inorganic multilayer films containing polyoxometalate and polyviologen via layer-by-layer self-assembly. Mater. Chem. Phys. 2013, 141, 482-487. [CrossRef]

44. Song, X.J.; Hu, D.W.; Yang, X.T.; Zhang, H.; Zhang, W.X.; Li, J.Y.; Jia, M.J.; Yu, J.H. Polyoxomolybdic Cobalt Encapsulated within Zr-Based Metal-Organic Frameworks as Efficient Heterogeneous Catalysts for Olefins Epoxidation. ACS Sustain. Chem. Eng. 2019, 7, 3624-3631. [CrossRef]

45. Du, J.; Yu, J.H.; Tang, J.Y.; Wang, J.; Zhang, W.X.; Thiel, W.R.; Jia, M.J. Supramolecular Assemblies Directed by Hydrogen Bonds and $\pi-\pi$ Interactions and Based on N-Heterocyclic-Ligand-Modified $\beta$-Octamolybdate-Structure and Catalytic Application in Olefin Epoxidation. Eur. J. Inorg. Chem. 2011, 15, 2361-2365. [CrossRef]

46. Charles, F.H.; Hendrik, C.A.; Van, B.; Pieter, M.H. Reactions of Some Peracids and Hydroperoxides with Cobalt(II) and Cobalt(III) Acetate in Acetic Acid Solution. Ind. Eng. Chem. Prod. Res. Dev. 1979, 18, $38-43$.

47. Wang, Q.B.; Cheng, Y.W.; Wang, L.J.; Li, X. Semicontinuous Studies on the Reaction Mechanism and Kinetics for the Liquid-Phase Oxidation of p-Xylene to Terephthalic Acid. Ind. Eng. Chem. Res. 2007, 46, 8980-8992. [CrossRef]

48. Denisov, E.T. Redox Reactions of Atoms and Radicals with Ions in Solution. Russ. Chem. Rev. 1971, 40, $24-32$. [CrossRef]

49. Kamiya, Y.; Ingold, K.U. The Metal-Catalyzed Autoxidation of Tetralin. Can. Jocrnal Chem. 1964, 42, 1027-1043. [CrossRef]

50. Navarro, M.; Escobar, A.; Landaeta, V.R.; Visbal, G.; Linares, F.L.; Luis, M.L.; Fuentes, A. Catalytic Oxidation of Tetralin by Biologically Active Copper and Palladium Complexes. Appl. Catal. A Gen. 2009, 363, 27-31. [CrossRef]

51. Chung, Y.M.; Ahn, W.S.; Lim, P.K. Organic-Water Interfacial Synthesis of $\alpha$-Tetralone Using Nickel-Tetraethylenepentamine Complex Catalysts. J. Catal. 1998, 173, 210-218. [CrossRef]

52. Sheldrick, G.M. SADABS; Siemens Analytical X-ray Instrument Division: Madison, WI, USA, 1995.

53. Sheldrick, G.M. SHELXL-97: A Program for Crystal Structure Determination; University of Gottingen: Gottingen, Germany, 1997.

(C) 2019 by the authors. Licensee MDPI, Basel, Switzerland. This article is an open access article distributed under the terms and conditions of the Creative Commons Attribution (CC BY) license (http://creativecommons.org/licenses/by/4.0/). 